coli and Salmonella typhimurium actually have three peptide permeases with different but overlapping specificities ${ }^{7.8}$. It is important when designing any peptide antibiotic that it enters the cell by more than one of these permeases such that at least two independent mutational events will be needed to develop resistance: this is, fortunately, the case for the new class of NHdKDO-peptide antibiotics.

Peptide transport systems of similar specificity are widespread, not only in microorganisms but also in plants ${ }^{y}$ and many mammalian tissues ${ }^{10}$. Thus, there are endless possibilities for designer herbicides and chemotherapeutic drugs. Finally, as was originally pointed out by Ames et $a l^{2}$, illicit transport via peptide transport systems can be an invaluable experimental tool, allowing circumvention of the permeability barrier and direction of otherwise impermeable molecules into the cytoplasm.

1. Hammond, S.M. et al. Nature 317, 730 (1987)

2. Ames, B.N. et al. Proc. natn. Acad. Sci. U.S.A. 70, 456 1973)

3. Fickel, T.E. \& Gilvarg, C. Nature 241, 161 (1973).

4. Payne, J.W. Microorganisms and Nitrogen Sources (Wiley, Chichester, 1980)

5. Murakami, T. et al. Molec. gen. Genet. 205, 42 (1986).

6. Kenig, M. \& Abraham, J. J. gen. Microbiol. 94, 37 (1976).

7. Higgins, C.F. \& Gibson, M.M. Meth. Enzym. 125, 365 (1984).

8. Hiles, I.D. et al. J. molec. Biol. 195, 125 (1987).

9. Higgins, C.F. \& Payne, J.W. Planta 138, 217 (1978)

10. Matthews, D.M. Physiol. Rev. 55, 537 (1976).

C'hris Higgins is in the Molecular Genetic Laboratory, Department of Biochemistry, University of Dundee, Dundee DDI 4HN, UK.

\title{
Oceanography
}

\section{Dense water off continents}

\section{John A. Whitehead}

Воттом water is the coldest and hence the most dense water in the ocean. It starts as surface water in polar regions such as the Greenland-Norwegian Sea, the Weddell Sea in Antarctica or the Labrador Sea, and sinks as it cools. But what are the specific details of the journey? A similar situation is found in inverse estuaries where evaporation causes water to be more saline and dense than the offshore sea water. Thus at the mouth of the estuary, sea water flows in over the dense water, which exits onto the continental shelf as a gravity current. Lennon and coworkers report on page 695 of this issue an outstandingly detailed study of such a process in Spencer Gulf in Australia. The lessons they learn can usefully be applied to the formation of bottom water.

There are two principal processes that convey cold, dense water in the polar regions from the surface to great depth. Both processes are difficult to observe directly because they occur only in a few inaccessible regions and often only at the height of winter. The first involves deepconvection events in which convection suddenly (over days to weeks) penetrates to great depth in deep oceanic basins at the coldest time. Such events have been observed only two or three times. The second process is the accumulation of extremely cold, salty and therefore dense water on the shallow continental shelves on the edge of the polar oceans. These dense waters migrate to the shelf break and flow down as shelf-break gravity currents, possibly channelled by submarine canyons.

This second process is thought to be particularly important in the formation of Antarctic bottom water, which is the most voluminous ocean bottom water. Water near, or on, the shelf of the Weddell Sea off the coast of Antarctica could form Antarctic bottom water. No observations have been made of the gravity current that would convey water from the shelf of the Weddell Sea to the deep ocean. Indirect evidence is found ${ }^{2}$ in the form of frontal structures near the shelf break. The flow of water implied by the front is towards the western end of the shelf. This region is permanently covered by ice and is inappropriate for an oceanographic survey in any season, so the gravity current might never be observed directly.

Fortunately, dense water elsewhere accumulates on shelves and migrates to the shelf break for other reasons, often on a smaller scale. The work of Lennon and colleagues in this issue ${ }^{\prime}$ is on one such system in Spencer Gulf, South Australia, where water is driven to high salinity by evaporation during the summer. In the early autumn, the water cools, sinks and spreads out along the bottom. In so doing it goes from the gulf onto the continental shelf and draws fresher water into Spencer Gulf from offshore. Once free of the confines of the gulf, the current of saline water veers to the left, possibly assisted by the Earth's rotation, and intersects the continental-shelf depth contours as a gravity current. Lennon and colleagues traced it all the way to the shelf break where it cascades off the shelf in the region of $\mathrm{Du}$ Covedic canyon.

Similar systems have been observed elsewhere. Dense water is formed in Bass Strait, South Australia ${ }^{3}$ in winter and follows the edge of the continental shelf in a narrow north-flowing stream creating high-salinity intrusions at $200-$ to $800-\mathrm{m}$ depth in the Tasman Sea. On the shelf at the northern end of the Adriatic Sea, dense water formation was observed ${ }^{+}$in the winter of 1961 . This water is said to be the main source of the abyssal water of the eastern-Mediterranean sea. A similar situation occurs in the Gulf of Lyons ${ }^{6}$, but the water there sinks to only $350 \mathrm{~m}$ and so does not contribute to deep water in the western-mediterranean basin.

There are also observations of such processes in the Gulf of Mexico'; in Funka Bay in Hokkaido, Japan by H. Miyake, I. Tanaka and T. Murakami (personal communication); and in the Adriatic Sea in 1980, 1981 and 1983 by L. Zoccolotti and E. Salusti (personal communication). The profusion of such processes suggests that the aggregate effect contributes to the ventilation of the ocean.

It is probably not appreciated how widespread this process is: none of the above studies refers to the others. In all cases, references to theoretical and laboratory experiments investigating the dynamics of such flows are also lacking. The effect of the Earth's rotation on bottomwater formation was excluded in a civilengineering study of lakes ${ }^{8}$, but included in another model applied to the oceans". The rotation causes gravity currents to lean to the right in the Northern Hemisphere and to the left in the Southern Hemisphere. Measurements have verified formulae like the Chezy equation used by Lennon and colleagues'. A similar formula with different theoretical and experimental bases, has been applied ${ }^{10}$ to the salt balance at Spencer Gulf. It predicts an excess of salt across the front in the mouth of the gulf that varies as a function of evaporation rate, and that agrees with the observed salinity. Such a calculation has also been verified for the front observed in Funka Bay.

The measurements by Lennon and colleagues have many implications beyond the local offshore oceanography they consider. This is true for the other studies as well. A combination of studies of localgravity currents in various bays and continental-shelfs, together with laboratory, numerical and theoretical studies, may even enable us to understand more clearly the situation in the Weddell Sea.

1. Lennon. G.W. et al. Nature 327. $695-697$ (1987).

2. Foster, T.D. \& Carmack. E.C. Deep-Sea Res. 23, $301-$ 317 (1976).

3. Tomczak. M. Jr Continental Shelf Res. 4, 255 - 278 (1985).

4. Hendershott, M.C. \& Rizoli, P.M. in La Formation des Eaux océaniques profondes Colloques int. Cent. natn. Rech. scient. no. 215, 135 - 138 (1974).

5. Zore, A. Acta Adriatica 10, 1 - 94 (1963)

6. Fleux, M. La Formation des Eaux océaniques profondes Colloques int. Cent. natn. Rech. scient. no. 215, 165-174 (1974)

Nowlin. W.D. Jr \& Parker. C.A. J. phys. Oceanogr. 4. 467 - 486 (1974).

8. Brocard, D.N., Jirka, G.H. \& Harlemann, D.R.F. in Ralph M. Parsons Laboratory for Water Resources and Hydrodynamics. tech. Rep. 223. (Dept. of Civil Engineering. Massachusetts Institute of Technology, 1977).

9. Sugimoto, T. \& Whitehead. J.A. J. phys. Oceanogr. 13. $1819-1828(1983)$

10. Bye. J.A.T. \& Whitehead, J.A. Jr Estuarine and Coastal Marine Science 3, 477 - 481 (1975)

John A. Whitehead is at the Department of Physical Oceanography, Woods Hole Oceanographic Institution, Woods Hole, Massachusetts 02543, USA. 